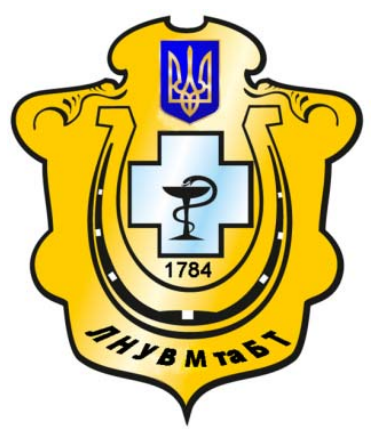

Науковий вісник Львівського національного університету ветеринарної медицини та біотехнологій імені С.3. Гжицького

Scientific Messenger of Lviv National University of Veterinary Medicine and Biotechnologies named after S.Z. Gzhytskyj

doi:10.15421/nvlvet7133

ISSN 2413-5550 print

ISSN 2518-1327 online

http://nvlvet.com.ua/

УДК 619:616-053.31:616.3

\title{
Етіологічна структура гострих шлунково-кишкових захворювань телят
}

\author{
А.В. Березовський, Т.І. Фотіна, Л.Г. Улько, О.Л. Нечипоренко, С.М. Тітов \\ tif_ua@meta.ua \\ Сумський національний аграрний університет, \\ вул. Г. Кондратьєва, 160, м.Суми, 40021, Украӥна
}

\begin{abstract}
У статті наведені результати досліджень проб біологічного матеріалу від телят з гострими илунково-кишковими захворюваннями. Встановлено, що у виникненні та розвитку гострих шлунково-кишкових захворювань провідну роль відіграють асоиіації умовно-патогенних бактерій: S. aureus, S. saprophiticus, S. agalactiae, S. faecalis, S. pyogenes, E. coli, E. cloacae, C. jejuni, P. vulgaris, P. mirabilis, P. aeruginosa ma K. pneumoniae

Більшість ізольованих культур нечутливі або слабочутливі до вивчених нами антибіотиків. Наведені дані є показником поширення антибіотикорезистентних штамів серед новонароджених телят у господарствах Сумської та Чернігівської областей, шьо пояснює низьку ефективність проведення антибіотикотерапії. Високоактивними по відношенню до культур S. aureus, S. saprophiticus, S. agalactiae, S. faecalis, S. pyogenes, E. coli, E. cloacae, C. jejuni, P. vulgaris, P. mirabilis, P. aеruginosa та K. pпеитопіае були препарат «Цефтіоклин» та комбіновані антибактеріальні засоби.

Ключові слова: телята, гострі шлунково-кишкові захворювання, умовно-патогенні мікроорганізми, антибактеріальні препарати, антибіотикорезистентність.
\end{abstract}

\section{Этиологическая структура острых желудочно-кишечных заболеваний телят}

\author{
А.В. Березовский, Т.И. Фотина, Л.Г. Улько, А.Л. Нечипоренко, Е.М. Титов \\ tif_ua@meta.ua
}

Сумской национальный аграрный университет,

ул. Г. Кондратьева, 160, г. Сумьи, 40021, Украина

В статье приведены результаты исследований проб биологического материала от телят с острыми желудочнокишечными заболеваниями. Установлено, что в возникновении и развитии острых желудочно-кишечных заболеваний ведущую роль играют ассочиащии условно-патогенных бактерий: S. aureus, S. saprophiticus, S. agalactiae, S. faecalis, S. pyogenes, E. coli, E. cloacae, C. jejuni, P. vulgaris, P. mirabilis, P. aeruginosa u K. Pneumoniae

Больиинство изолированных культур нечувствительны или слабочувствительны к изученным нами антибиотикам. Приведенные данные являются показателем распространения антибиотикорезистентных штаммов микроорганизмов среди новорожденных телят в хозяйствах Сумской и Черниговской областей, что объясняет низкую эффективность проведения антибиотикотерапии. Высокоактивными по отношению к культурам S. aureus, S. saprophiticus, S. agalactiae, S. faecalis, S. pyogenes, E. coli, E. cloacae, C. jejuni, P. vulgaris, P. mirabilis, P. aeruginosa и K. pneumoniae были препарат «Цефтиоклин» и комбинированные антибактериальные средства.

Ключевые слова: телята, острые желудочно-кишечные заболевания, условно-патогенные микроорганизмы, антибактериальные препараты, антибиотикорезистентность.

\section{Citation:}

Berezovskyi, A., Fotyna, T., Ulko, L., Nechyporenko, A., Tytov, E. (2016). Etiological structure of acute gastrointestinal diseases of calves. Scientific Messenger LNUVMBT named after S.Z. Gzhytskyj, 18, 3(71), 148-151. 


\title{
Etiological structure of acute gastrointestinal diseases of calves
}

\author{
A. Berezovskyi, T. Fotyna, L. Ulko, A. Nechyporenko, E. Tytov \\ tif_ua@meta.ua \\ Sumy National Agrarian University, \\ G. Kondratiev Str., 160, Sumy, 40021, Ukraine
}

\begin{abstract}
The results of tests of samples of biological material from the calves with acute gastrointestinal diseases presents in the article. It was found that the occurrence and development of acute gastrointestinal diseases the leading role played by opportunistic bacteria association: S. aureus, S. saprophiticus, S. agalactiae, S. faecalis, S. pyogenes, E. coli, E. cloacae, C. jejuni, P. vulgaris, P. mirabilis, $P$. aeruginosa and K. Pneumoniae. Of the 632 examinations we studied 2,786 samples of biological material. Analysis of the results on our diagnostic work shows that acute gastrointestinal disease in calves caused by microbial associations. At acute gastrointestinal disease isolated pathogen E. coli-21.0\%. Coccoid microorganisms group also had significant representation. Thus, a biomaterial of $15.5 \%$ was allocated $S$. faecalis, at $11.6 \%$ was allocated pathogen $S$. aureus. Although to a lesser extent, but large office in the species spectrum of microorganisms by acute gastrointestinal diseases of calves occupied S. agalactiae $-4.8 \%$, S. saprophiticus $-4.6 \%$, S. pyogenes $-3.7 \%$. Among the important place occupied microorganisms culture P. vulgaris - $8.5 \%$ of the total allocation of the samples. The average discharge frequency was characteristic for Campylobacter jejuni - $6.5 \%$ of cases.

In analyzing the sensitivity of microorganisms isolated from calves with acute gastro-intestinal diseases to different groups of antibiotic drugs found that E. coli has a low sensitivity to antibiotics almost all studied groups. The largest number of selected crops susceptible to cephalosporins $-74.8 \%$. Most of the isolated cultures weaklysensitive or insensitive to antibiotics studied by us. These data are an indication of the spread of antibiotic-resistant strains of microorganisms among newborn calves in the farms of Sumy and Chernihiv regions, which explains the low efficiency of antibiotic therapy. Highly active towards crop $S$. aureus, S. saprophiticus, S. agalactiae, S. faecalis, S. pyogenes, E. coli, E. cloacae, C. jejuni, P. vulgaris, P. mirabilis, P. aeruginosa, and K. pneumoniae were drug "Ceftioklin» and combined antibacterial agents.
\end{abstract}

Key words: calves, acute gastro-intestinal diseases, opportunistic pathogens, antibiotics, antibiotic resistance.

\section{Вступ}

Гострі шлунково-кишкові захворювання (ГШКЗ) молодняку великої рогатої худоби залишаються надзвичайно актуальною проблемою сучасного тваринництва. На особливу увагу заслуговують гострі шлунково-кишкові захворювання у телят в неонатальний період (Arbuzova, 2010; Kotsiumbas et al., 2015). Адже власне в цьому віці у зв'язку з незрілістю механізмів імунного захисту і неспецифічної резистентності організму ГШКЗ характеризуються значною частотою розвитку тяжких форм хвороби, потенційно небезпечних навіть в плані летального наслідку.

Завдяки сучасним досягненням мікробіології, вірусології та імунології

встановлено постійне розширення спектру етіологічних чинників ГШКЗ. У їх етіології беруть участь віруси, бактерії, хламідії та інші збудники як окремо, так і найчастіше в різних асоціаціях (Gafarov et al., 2002; Hadzevych et al., 2013). Попри різноманітності суджень щодо спричинення гострих діарейних захворювань патогенними бактеріями, роль умовнопатогенних мікроорганізмів як етіологічних чинників ГШКЗ на сьогодні залишається дискусійною. Виділення умовно-патогенних бактерій за гострих шлунково-кишкових розладів здебільшого вважають проявом локальних дисбіотичних порушень. Проте в останні роки все частіше з'являються повідомлення про спричинення гострих кишкових інфекцій асоціацією умовно-патогенних бактерій. За останні роки відбулися значні зміни у структурі збудників хвороб сільськогосподарських тварин. Значно збільшилась питома вага умовно-патогенних мікроорганізмів, серед яких провідне місце займають мікроорганізми родів Streptococcus та Staphylococcus. Вони здатні викликати захворювання з різноманітними клінічними проявами (Myshchenko et al., 2008).

Незважаючи на досягнення в питаннях лікування молодняку тварин за шлунково-кишкової патології $\epsilon$ об'єктивні складності у визначенні етіологічної структури, патогенезу, проведенні диференціального діагнозу і в підходах до фармакокорекції.

Відомо також, що ГШКЗ молодняку великої рогатої худоби часто перебігають по типу асоціаційованої інфекції. В їх етіології, поряд з несприятливими факторами, велику роль відіграє асоціація патогенної та умовно-патогенної мікрофлори. Крім того, виникнення ГШКЗ і ступінь їх тяжкості в певній мірі залежить від таких факторів, як умови утримання, природна резистентність і імунологічна реактивність організму (Svensson et al., 2003; Babenko, 2006; Gulliksen et al., 2009).

Метою дослідження було на основі даних клінічних спостережень та результатів бактеріологічних досліджень визначити етіологічну структуру гострих шлунково-кишкових захворювань новонароджених телят та дослідити чутливість культур мікроорганізмів, ізольованих від хворих тварин до антибіотиків.

\section{Матеріал і методи досліджень}

У роботі використано культури мікроорганізмів ізольовані впродовж 2014 - 2016 років від телят 3 ГШКЗ із різних господарств Сумської та Чернігівської областей. Матеріалом для дослідження були проби патологічного матеріалу відібраного від телят 3 ГШКЗ. Виділення та ідентифікацію культур мікроорганізмів проводили в декілька етапів: мікроскопія; висів на середовища збагачення та диференційнодіагностичні середовища; вивчення морфологічних, культуральних та біохімічних властивостей, патоген- 
ності для тварин. Видову ідентифікацію виділених культур мікроорганізмів проводили за допомогою «Определителя бактерий Берджи». Ідентифікацію виділених культур стафілококів проводили шляхом висіву на диференційно-діагностичне середовище: жовтково-сольовий агар з 10\% хлористого натрію для визначення лецитиназної активності і на кров'яний МПА для визначення гемолітичних властивостей. Також визначали коагулазну активність використовуючи плазму крові кроля, вивчали ферментацію маніту і збродження глюкози. Здатність мікробів коагулювати плазму вивчали, використовуючи центрифугат свіжої, стерильно взятої крові кролика, що містить $1 \%$ цитрату або суху кролячу плазму, розведену фізіологічним розчином. Нативну плазму розводили ізотонічним розчином у співвідношенні 1:4. Її розливали стерильно у пробірки по 0,5 мл і вносили туди по 1 петлі досліджуваної добової агарової культури. Висіви ставили в термостат при $\mathrm{t} 37^{\circ} \mathrm{C}$ і через $1,2,4$, 18 і 24 години проводили облік результатів. Позитивною вважали реакцію по наявності в пробірках згустку будь-якої величини і конфігурації. При цьому плазмокоагулююча активність находиться в зворотній пропорційній залежності від часу утворення згортка в пробірці.

3 метою виділення культур стрептококів висіви проводили на кров'яний МПА з 1\% глюкози. Ідентифікацію стрептококів здійснювали за визначенням типу гемолізу, ростом на МПБ з 40\% жовчі, ферментацією сахарози лактози маніту.

Для визначення гемолітичних властивостей виділених культур використовували 5\% кров'яний агар. Культури засівали, інкубували при t $37^{\circ} \mathrm{C}$ і продивлялись через кожні 24 години. Зону гемолізу навколо колоній мікроорганізмів визначали в міліметрах від краю до краю.

Для виділення E. coli використовували середовище Ендо, Левіна. При ідентифікації культур вивчали ферментативну активність на середовищах 3 лактозою, сахарозою. Культури, які за морфологічними ознаками, культуральними і ферментативними властивостями відповідали E. coli, ідентифікували в реакції аглютинації з специфічними О-колі сироватками і визначали патогенні сировари.

Культури зберігали в пробірках зі скошеним м'ясо-пептонним агаром в холодильнику за температури $4{ }^{\circ} \mathrm{C}$, субкультивуючи щоденно. Визначення чутливості проводили диско-дифузійним методом 3 наступним набором дисків: амоксицилін (АМО), ампіцилін (АМП), гентаміцин (ГЕН), доксициклін (ДОК), енрофлоксацин (ЕНР), канаміцин (КАН), лінкоміцин (ЛІН), левоміцетин (ЛЕВ), норфлоксацин (НОР), оксацилін (ОКС), пеніцилін (ПЕН), рифампіцин (РИФ), стрептоміцин (СТР), тетрациклін (ТЕТ), цефтіоклин (ЦЕФ).

Для приготування інокуляту використовували добову культуру, з якої готували суспензію, що відповідала 0,5 стандарту мутності McFarland. Для перевірки якості дисків, поживного середовища та правильності методики постановки тесту використовували еталонні штами E. coli, S. aureus та P. aeruginosa.

\section{Результати та їх обговорення}

Зважаючи на те, що в розвитку патологічного процесу головну роль відіграють представники умовнопатогенної та патогенної мікрофлори, нами було вивчено видовий спектр мікроорганізмів за ГШКЗ у телят

Із 632 експертиз нами досліджено 2786 проби біоматеріалу. Аналіз результатів проведеної нами діагностичної роботи засвідчує, що ГШКЗ у телят викликані асоціаціями мікроорганізмів. Як видно із таблиці 1 за ГШКЗ найчастіше ізолювали збудник E. coli $21,0 \%$.

Таблиия 1

Видовий спектр мікроорганізмів виділених із біоматеріалу від телят із гострими шлунковокишковими захворюваннями

\begin{tabular}{|l|c|c|}
\hline \multirow{2}{*}{$\begin{array}{c}\text { Ідентифіковані культур } \\
\text { мікроорганізмів }\end{array}$} & \multicolumn{2}{|l|}{$\begin{array}{c}\text { Проби з яких ізольовані } \\
\text { штами мікроорганізмів }\end{array}$} \\
\cline { 2 - 3 } & $\begin{array}{c}\text { абсолютне } \\
\text { число }\end{array}$ & $\%$ \\
\hline Staphylococcus aureus & 324 & 11,6 \\
\hline Streptococcus saprophiticus & 128 & 4,6 \\
\hline Streptococcus agalactiae & 134 & 4,8 \\
\hline Streptococcus faecalis & 432 & 15,5 \\
\hline Streptococcus pyogenes & 102 & 3,7 \\
\hline Escherichia coli & 586 & 21,0 \\
\hline Enterobacter cloacae & 326 & 11,7 \\
\hline Campylobacter jejuni & 181 & 6,5 \\
\hline Proteus vulgaris & 236 & 8,5 \\
\hline Proteus mirabilis & 157 & 5,6 \\
\hline Pseudomonas aeruginosa & 97 & 3,5 \\
\hline Klebsiella pneumoniae & 83 & 3,0 \\
\hline Bcьoго & 2786 & 100,0 \\
\hline
\end{tabular}

Кокова група мікроорганізмів також мала вагоме представництво. Так, із біоматеріалу у 15,5\% було виділено S. faecalis, у 11,6\% було виділено збудник S. aureus. Хоча і в меншій мірі, але значне своє представництво в видовому спектрі мікроорганізмів за ГШКЗ у телят займали $\mathrm{S}$. agalactiae $-4,8 \%$, S. saprophiticus 4,6\%, S..pyogenes $-3,7 \%$.

Серед асоціантів вагоме місце займали культури Р. vulgaris - до 8,5\% випадків виділення від загальної кількості досліджених зразків. Середня частота виділень була характерна для Campylobacter jejuni - 6,5\% випадків.

При аналізі чутливості мікроорганізмів виділених від телят з ГШКЗ до різних груп антибіотичних препаратів встановлено, що E. coli має низьку чутливість до антибіотиків майже всіх вивчених груп. Найбільша кількість виділених культур чутливі до цефалоспоринів $-74,8 \%$.

Серед вивчених культур S. aureus резистентними до амоксициліну, гентаміцину, канаміцину, левоміцетину та стрептоміцину були $16 \%$, до пеніциліну $36 \%$.

Культур S. pyogenes резистентних до амоксициліну, канаміцин, доксицикліну, енрофлоксацину, кана- 
міцину, норфлоксацину, оксациліну, рифампіцину, стрептоміцину, тетрацикліну та цефтіоклину не було.

Усі виділені культури P. vulgaris володіли високою чутливістю до амоксициліну, доксицикліну, левоміцетину, тетрацикліну та цефтіоклину. Канаміцин, лінкоміцин та цефтіоклин проявляли однакову високу активність відносно E. coli.

Ентерококи виявили чутливість до макролідів та глікопептидів. Відносно стафілококів найбільшу активність проявляли антибіотики цефалоспоринового ряду, а також комплексні препарати. Стрептококи були чутливі до макролідів, кількість чутливих культур становила 38,6\%. Культури клебсієл проявляли чутливість до цефалоспоринів (62,3\% чутливих культур). Ефективність антимікробних препаратів інших груп щодо K. pneumonia була низькою. Високоактивні щодо P. vulgaris були препарати групи цефалоспоринів - 68,3\% чутливих культур. Культури роду Proteus spp. були чутливі до більшості використаних антибіотиків. Кількість чутливих культур за застосування препаратів групи аміноглікозидів становила 39,7\%, цефалоспоринів - 74,2\%, фторхінолонів - 58,7\%, левоміцетину - 52,6\% і 86,4\% при використанні комплексних препаратів. Цефтіоклин був високоактивним по відношенню до культур $S$. aureus, S. saprophiticus, S. agalactiae, S. faecalis, S. pyogenes, E. coli, E. cloacae, C. jejuni, P. vulgaris, P. mirabilis, $P$. aeruginosa та $K$. pneumoniae

Таким чином, нечутливими або слабочутливі до впливу вивчених нами антибіотичних препаратів були 7 - 100\% бактеріальних культур різних видів, виділених від телят з ГШКЗ. Наведені дані $є$ показником поширення антибіотикорезистентних штамів серед новонароджених телят у господарствах Сумської та Чернігівської областей, що пояснює низьку ефективність проведення антибіотикотерапії.

\section{Висновки}

1. У виникненні та розвитку гострих шлунковокишкових захворювань провідну роль відіграють асоціації умовно-патогенних бактерій: S. aureus, S. saprophiticus, S. agalactiae, S. faecalis, S. pyogenes, E. coli, E. cloacae, C. jejuni, P. vulgaris, P. mirabilis, $P$. aeruginosa та $K$. pneumoniae

2. Високоактивними по відношенню до культур $S$. aureus, S. saprophiticus, S. agalactiae, S. faecalis, S. pyogenes, E. coli, E. cloacae, C. jejuni, P. vulgaris, $P$. mirabilis, $P$. aeruginosa та $K$. pneumoniae був препарат «Цефтіоклин» та комбіновані антибактеріальні препарати.
Перспективи подальших досліджень. Перспективними є дослідження терапевтичної ефективності застосування препарату «Цефтіоклин» за умов гострих шлунково-кишкових захворювань молодняку великої рогатої худоби. Визначення впливу даного препарату на організм телят за гострих шлунково-кишкових розладів.

\section{Бібліографічні посилання}

Kotsiumbas, I.Ia., Petryshyn, O.B., Brezvyn, O.M., Rudyk, H.V. (2015). Vplyv danofloksatsynu na orhanizm teliat za umov shlunkovo-kyshkovykh zakhvoriuvan. Naukovyi visnyk LNUVMBT imeni S.Z. Gzhytskoho. Lviv. 17, 2(62), 87-91 (in Ukrainian).

Arbuzova, A.A. (2010). Mikstinfekcija, kak prichina ostryh kishechnyh boleznej teljat. Uchenye zapiski Kazanskoj gosudarstvennoj akademii veterinarnoj mediciny im. N.Je. Baumana. Kazan'. 203, 19-25 (in Russian).

Gafarov, H.Z., Ivanov A.V., Nepoklonov, E.A. (2002). Mono- i smeshannye infekcionnye diarei novorozhdennyh teljat i porosjat. Kazan': izd-vo «Fjen» (in Russian).

Hadzevych, D.V., Dunaiev, Iu.K., Horbenko, O.V., Hadzevych, O.V. (2013). Efektyvnist vaktsynoprofilaktyky stafilokokovykh ta streptokokovykh zakhvoriuvan u skotarskykh hospodarstvakh. Vet. medytsyna: Mizhvid. tematych. nauk. zb. - Kh. 97, 162-164 (in Ukrainian).

Myshchenko, V.A. Pavlov, D.K., Dumova, V.V. (2008). Struktura zabolevanij pishhevaritel'noj sistemy novorozhdennyh teljat. Veteryanaryia Kubany. 5, 3437 (in Russian).

Babenko, O.P. (2006). Tsyrkuliatsiia umovno-patohennoi mikroflory sered velykoi rohatoi khudoby riznoho viku. Zbirnyk naukovykh prats Lvivskoi natsionalnoi akademii veterynarnoi medytsyny im. S.Z. Gzhytskoho. Lviv. 8, 3(30), 10-13 (in Ukrainian).

Svensson, C., Lundborg, K., Emanuelson, U., Olsson, S. (2003). Morbidity in Swedish dairy calves from birth to 90 days of age and individual calf-level riskfactors for infectious diseases. Prev. Vet Med. 58, 179-197.

Gulliksen, S.M., Lie, K.I., Osteras, O. (2009). Calf health monitoring in Norwegian dairyherds. J Dairy Sci, 92, 1660-1669.

Стаття надійшла до редакиії 2.10.2016 